\title{
The City of the Future
}

\author{
A new paradigm, a new vocabulary
}

Author 1: Esther Vlaswinkel, Urban designer MSc and director of SVP; The Netherlands

\begin{abstract}
THE CITY IN WHICH EVERYTHING IS CONNECTED TO EVERYTHING

To design the city of the future, we have to stop extrapolating the problems of today. This is why team Stadsvrijheid developed a new conceptual framework, a new paradigm for the future. On the basis of this paradigm, the team argues back to the here and now. This approach requires different ordering principles and new design tools, in short: the development of a completely new vocabulary.
\end{abstract}

Current ordering principles such as density and functions will no longer be applicable in the future, which will centre on length of residence, production potential and the intricacy of the urban fabric. Combinations of these factors determine the DNA of an area. The team's conceptual framework for the future sketches a new world in which everything is connected to everything; people as well as things. Technology plays an important role in this. In the resulting circular economy, everything is productive.

The test site for this new paradigm was Utrecht's eastern fringe. This promising location allows the interweaving of landscape and city in the context of today's urbanization pressure. It is precisely in the monofunctional and fragmented urban fringes that a new type of urban character can emerge by connecting new developments in the field of mobility and technology.

Anyone who wants the city to be liveable and healthy has to move towards a city in which walking is the norm and therefore away from 'radial thinking' of the traditional city. The outskirts of Utrecht will become gateways to the city or even the Randstad, with the Sciencepark as the global attractor and the Lunetten hub as the global connector.

The team translated the contours of the conceptual framework into ordering principles and balanced these using a 'mixing console'. Important principles are: the intricacy of the urban fabric (everything is connected), travel time (everything is proximate), length of residence (everything takes its own time) and varied production (everything is productive). The mixing console allows an alternative method of organizing areas according to functions or density. A specific mix determines the DNA of a region.

The team devised new design tools to create the city of the future. The 'armature', for example, is a tool that can be used to redefine the current road infrastructure. Development along the $Z$ axis, for example, is based on the principles of urban stratigraphy and builds on the strata of the existing city. This allows densification and the current physical barriers such as the motorways will transform into layered landscapes that will act as hubs connecting future centres.

In 2040, city dwellers travel by foot and motorized transport between cities will be connected collectively or individually. The resulting city is a continuous city for pedestrians that not only allows more density, but in which there is more room for greenery as well. Functions such as 
roads and housing are layered, stackable, connectable entities linked to new energy and transport networks. They create a productive and endlessly connected urban landscape.

In this layered city everything, including waste, produces something. Everything is designed to last a certain period of time, for example based on length of residence. In this city, the cost of space is the driving force behind change. This comes with new investment models in which the relationship between interest and involvement play a part.

Team Stadsvrijheid consists of designers and specialists of SVP, OKRA landschapsarchitecten, Cross Architecture, Advier, Thefutureinstitute, Info.nl, BPD and The Missing Link

\section{Keywords}

Future city, new vocabulary 


\section{The Landscape as the Basis for an Intensive and Healthy City}

\subsection{Situation}

The outskirts in the east of Utrecht are fragmented. Office locations, residential neighbourhoods of all kinds and recreational functions typical of urban fringes, such as sports fields and a stadium, determine the atmosphere. In addition, substantial infrastructure bundles such as roads, the new tram line and the railway track cut across the area.

Waterlinieweg, which is part of the Dutch Water Line, traditionally bounds the area to the west and guards the border between city and surrounding landscape. The New Dutch Water Line is of high spatial and cultural-historical value. Utrecht's eastern outskirts contain perfectly beautiful forts and defences, which currently go largely unnoticed. In the years that new construction in the area has been permitted - which it previously was not because of its military significance - some scattered locations have been developed. The ambition is to give the area more cohesion and to link its transformation to the improvement of the existing green structures.

\subsection{Spearheads: intensive and inclusive utility value and new mobility systems}

Utrecht is growing, the use of the city centre is increasingly intensive and there is growing pressure on its scarce open spaces. Stadsrand Oost's green basis can potentially change from a monofunctional to an intensively used and socially inclusive area that meets the conditions of healthy urbanization. The eastern outskirts of Utrecht can accommodate urban functions and will therefore allow the densifying city some breathing space.

In addition, the quest is on for new mobility systems that are light and adaptable and will improve access to the fragmented area and connect it with the city and the region. The existing infrastructure of car lanes, train tracks and the soon to be opened new Uithof Line are obstacles as well as connections. What will this area look like in the distant future? Is light rail the solution or will the system have to become more and less radially-oriented? And what role can Waterlinieweg play in this development?

\subsection{Challenge}

The growth of Utrecht and the densification of the existing city create opportunities to transform Oostelijke Stadsrand into a metropolitan living, working and recreational landscape. A well-proportioned landscape design can bring back coherence and make the cultural-historical layers experienceable. The challenge is to combine this with more intensive use, densification and accessibility. How can the city achieve this while maintaining a good spatial, social and economic balance?

Healthy urbanization is the starting point every time. This means the focus is on exercise, well-being and sustainability and on living, employment and education. This calls for a living environment that is designed to actually have positive effects on health and that encourages healthy behaviour. 


\section{New paradigm, new vocabulary}

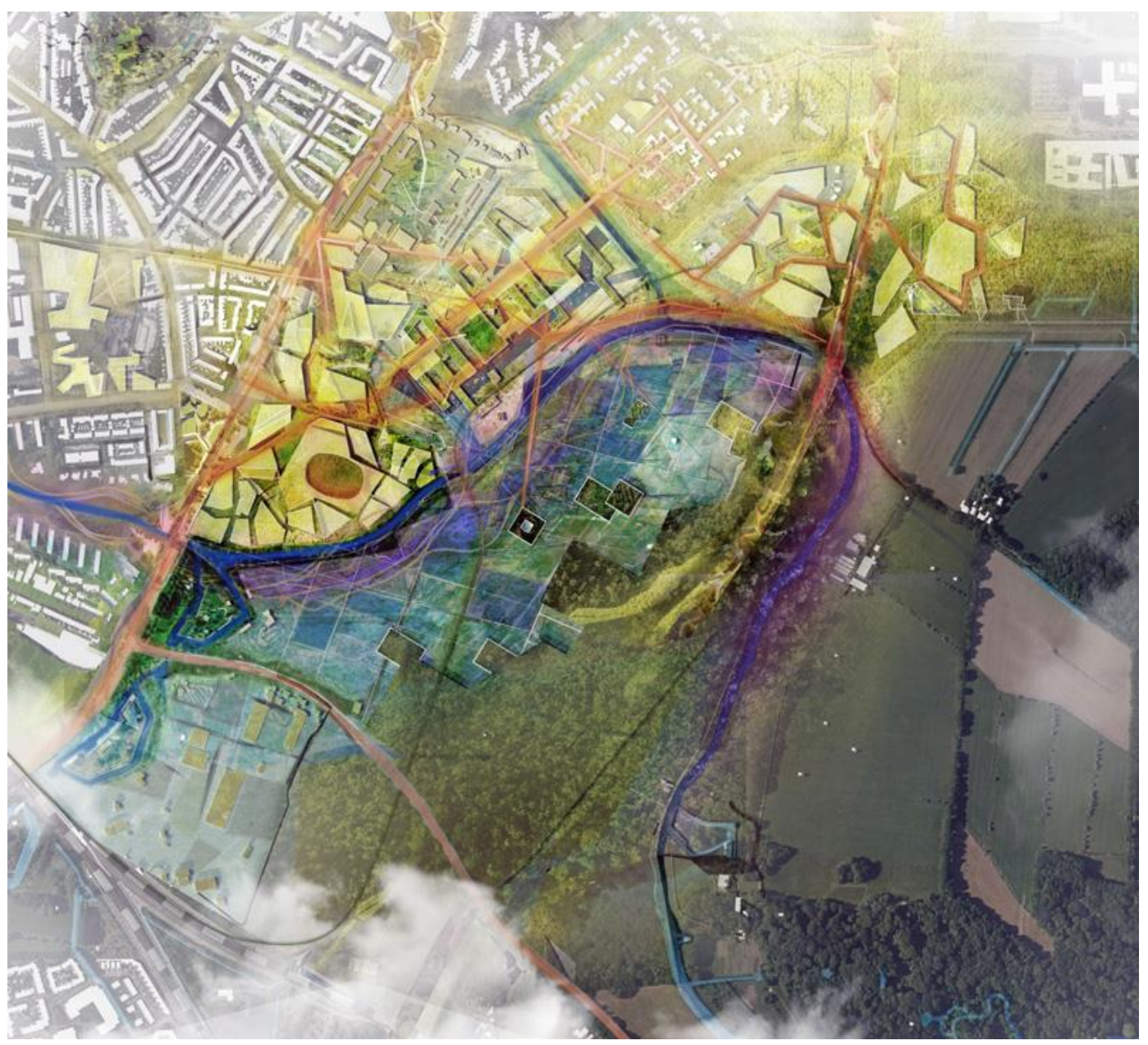

Figure 1 Test plan 'Stadsvrijheid' (urban freedom): The term stadsvrijheid, which denoted the area outside the city walls in the Middle Ages, today once again denotes space in which there is room for experiment.

To design the city of the future, we have to stop extrapolating the problems of today. This is why team Stadsvrijheid developed a new conceptual framework, a new paradigm for the future. On the basis of this paradigm, the team argues back to the here and now. This approach requires different ordering principles and new design tools, in short: the development of a completely new vocabulary.

Current ordering principles such as density and functions will no longer be applicable in the future, which will centre on length of residence, production potential and the intricacy of the urban fabric. Combinations of these factors determine the DNA of an area. The team developed these ordering principles on a test site.

The team's conceptual framework for the future sketches a new world in which everything is connected to everything; people as well as things. Technology plays an important role in this. In the resulting circular economy, everything is productive. 
The test site for this new paradigm was Utrecht's eastern fringe. This promising location allows the interweaving of landscape and city in the context of today's urbanization pressure. It is precisely in the monofunctional and fragmented urban fringes that a new type of urban character can emerge by connecting new developments in the field of mobility and technology.

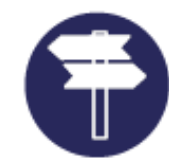

Figure 2A

Movement is everywhere Mobility will be a commodity. Design will not take existing forms of infrastructure into account.

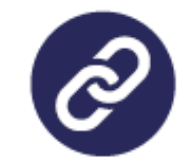

\section{Figure 2B}

Everything is connected In addition to people, objects are also part of the network, connected to it and operating independently.

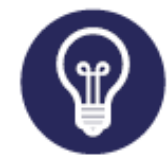

Figure 2C

Everything produces something

In the circular economy, everything produces something. Waste is raw material and health clubs generate energy.

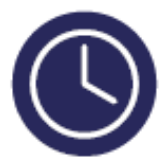

Figure 2D

People's perception of time is layered. We no longer build for 'as long as possible', but for 'long enough'.

\section{0} 2025 2030 2035
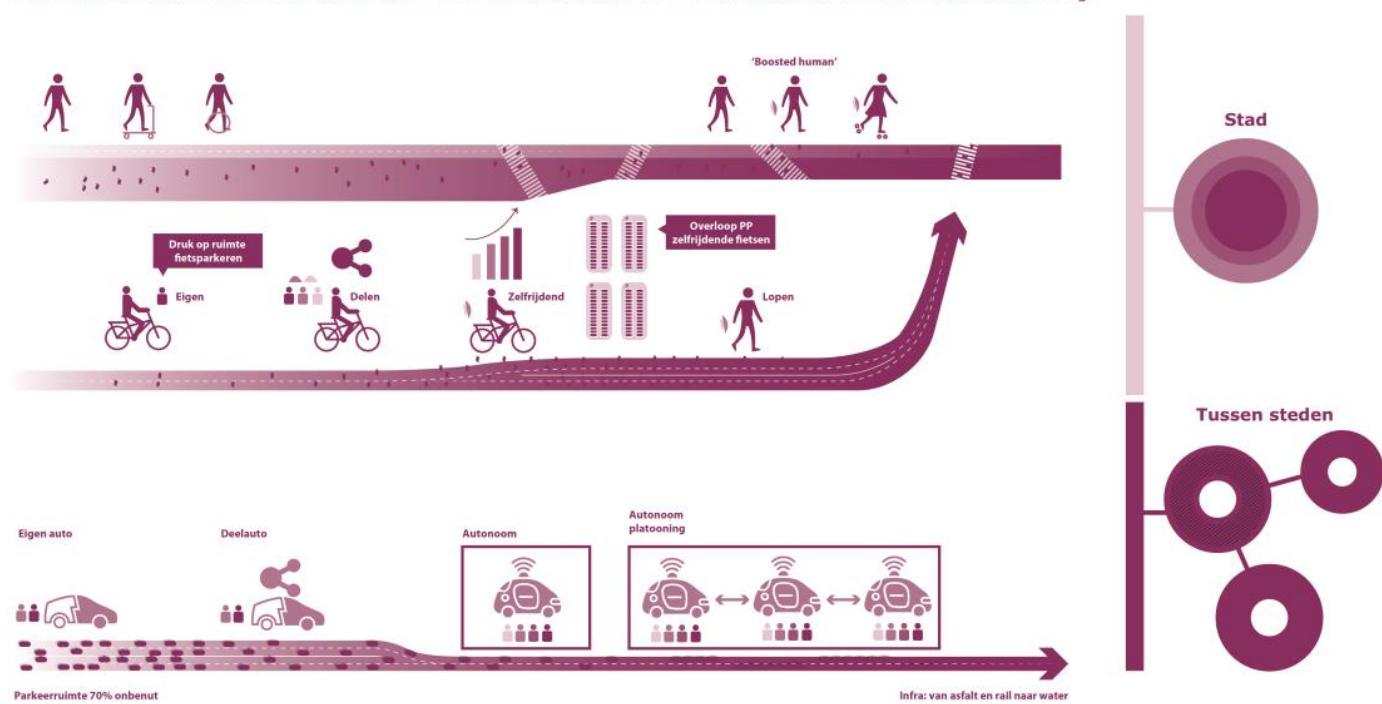

Figure 3 The cost of space is the driving force behind change: human dimensions are the most efficient. By 2040, the test site no longer needs any large-scale transport. The Lunetten and Science Park hubs and the intricate urban fabric ensure that every destination in the area is within walking distance. 


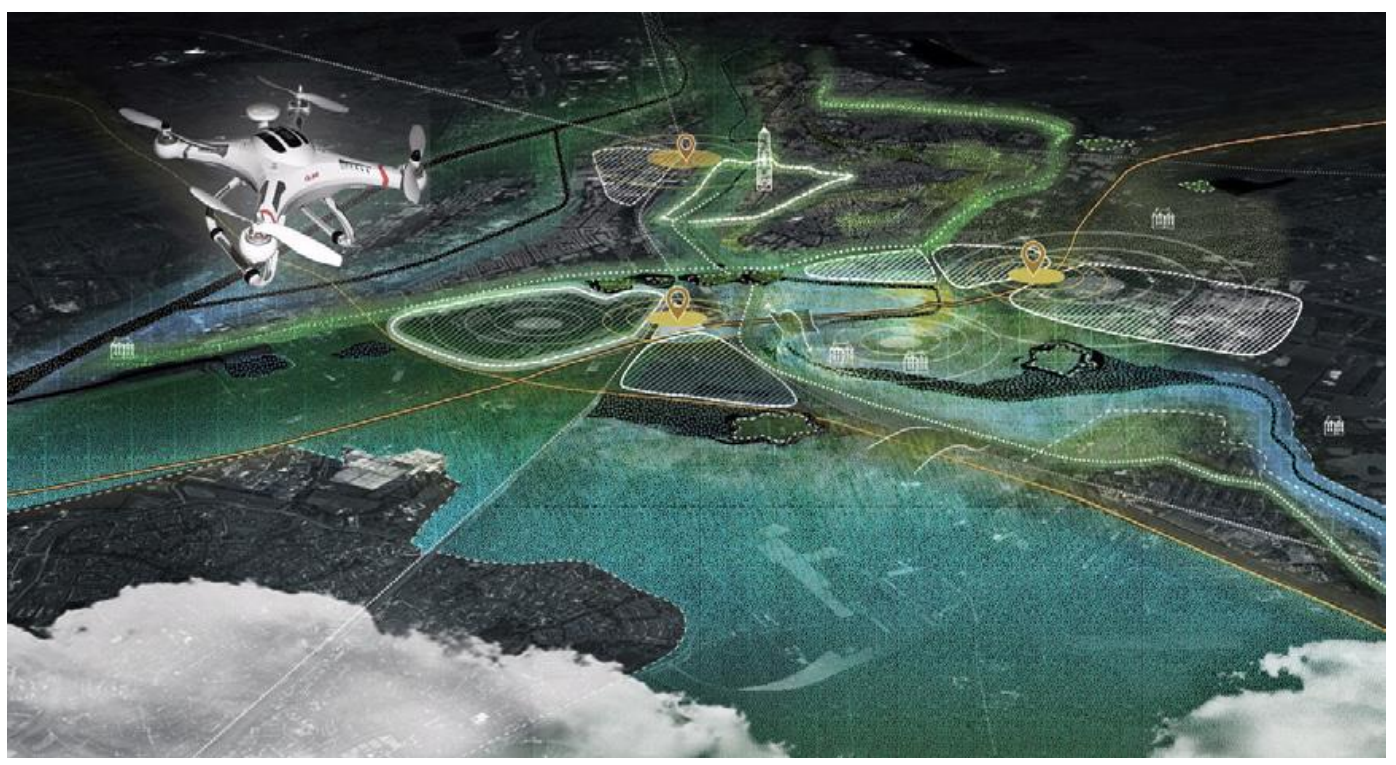

Figure 4 West to east transformation: from back of the city to front of the city (Lunetten, Sciencepark and Kromme Rijn landscape).

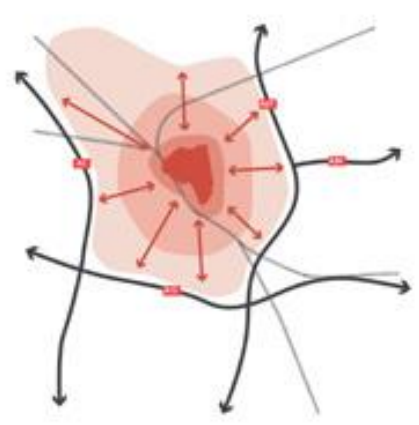

Figure $5 A / B / C$

Utrecht today: radial thinking

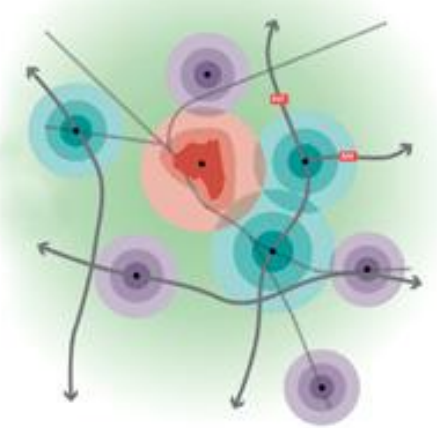

Utrecht 2040:

Complementary centres

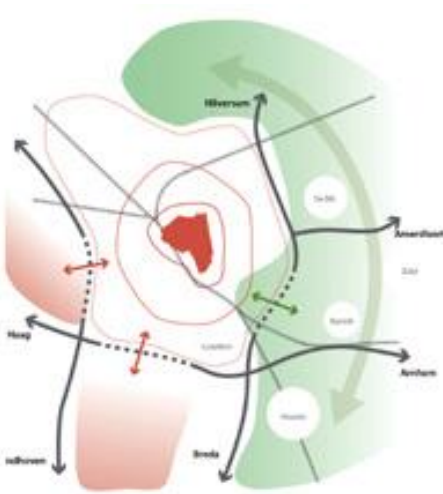

Utrecht 2040: \#030 integration

\subsection{Complementary Centres}

Team Stadsvrijheid wants to create a healthy city with a large variety of living environments in which the human dimension is the starting point for every intervention. The team also considers connecting the existing city with its outskirts as an important task. After all, the infrastructure that is intended to ensure accessibility also cuts the city into segments and often creates barriers that stand in the way of good connections. 


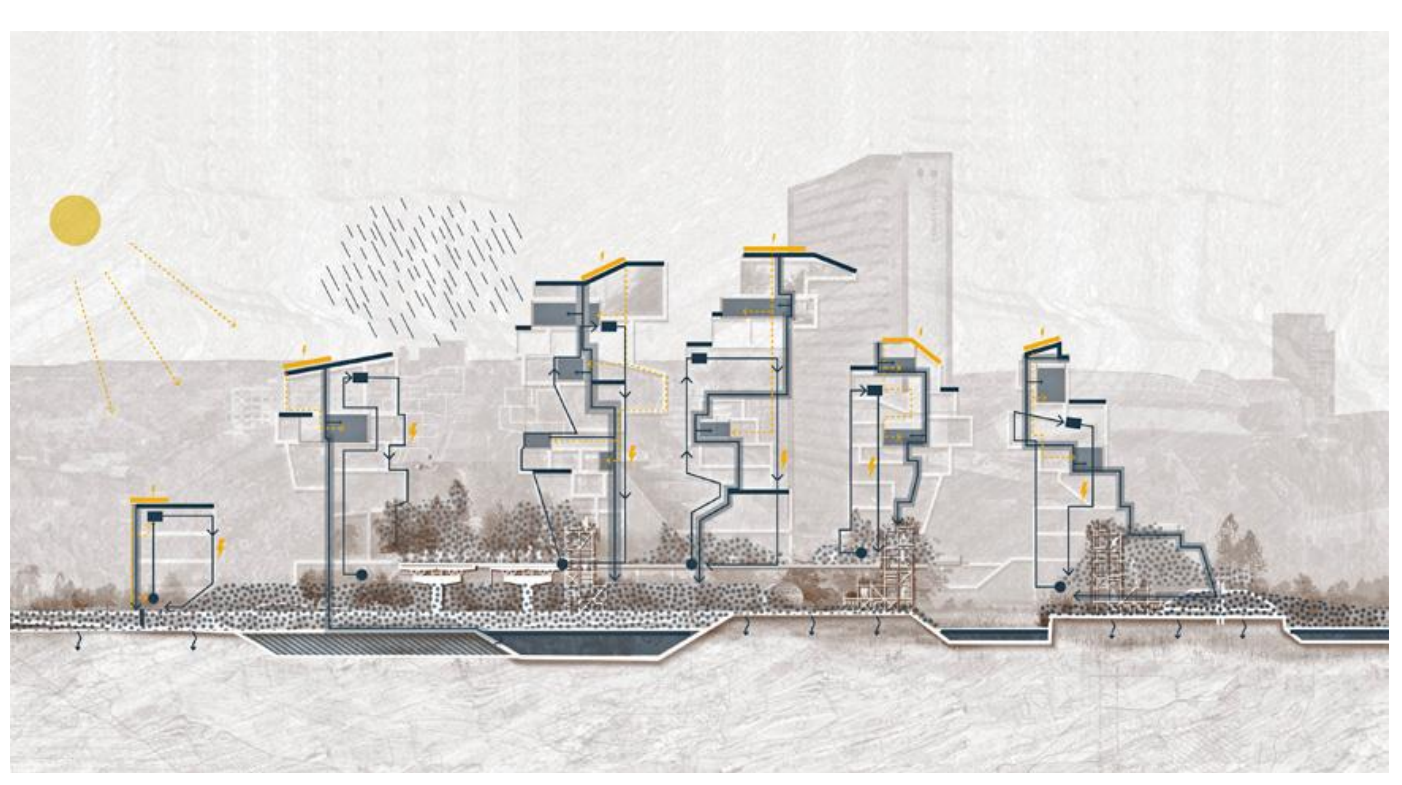

Figure 6 The landscape as a valve that controls the flow of water to the city: 70 per cent of the water in the canal system originates from the Kromme Rijn River. In 2040, the meandering 'water machine' will result in a stronger current, less sedimentation, cleaner water and new ecological connections to the city. Locally, the river will become important as a climateadaptive production and recreational landscape and as the Arcadian backdrop of the city's new front.

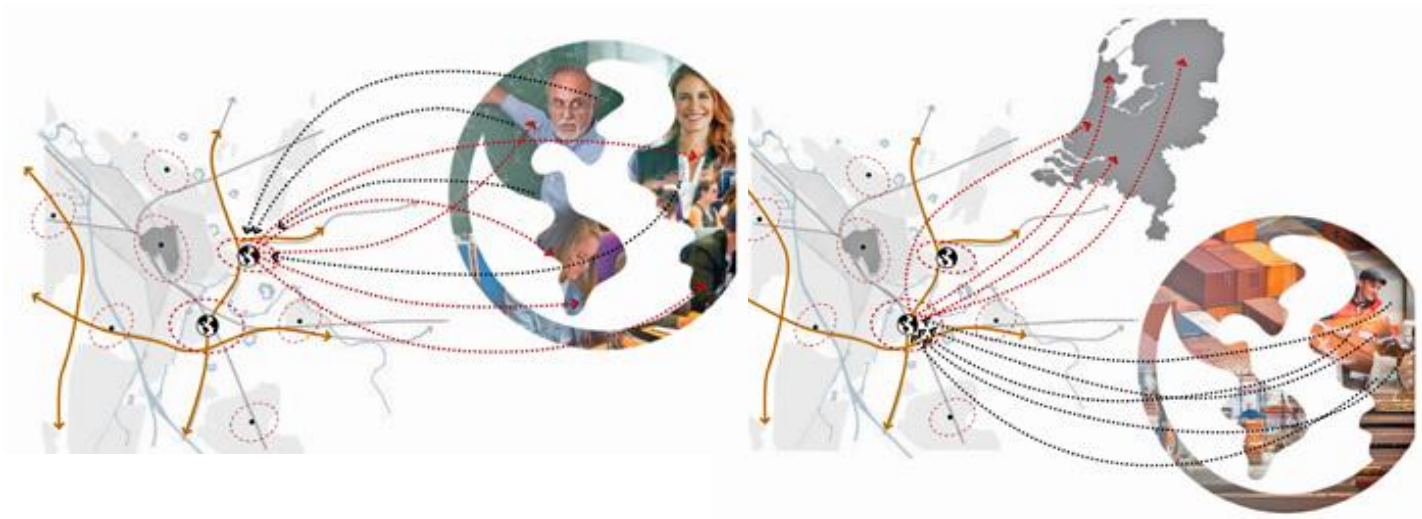

Figure 7A Science Park: 'global attractor'

Figure 7B Lunetten: 'global connector'

Anyone who wants the city to be liveable and healthy has to move towards a city in which walking is the norm and therefore away from 'radial thinking'. By looking at Utrecht as a city with several complementary centres rather than a single centre-oriented city, specific places in the outskirts of Utrecht that can serve as hubs of connections with the region and the rest of the world catch the eye. The outskirts of the city will become gateways to Utrecht or even the Randstad, with the Sciencepark as the global attractor and the Lunetten hub as the global connector, and thus change from the B-side of the city to its A-side. 


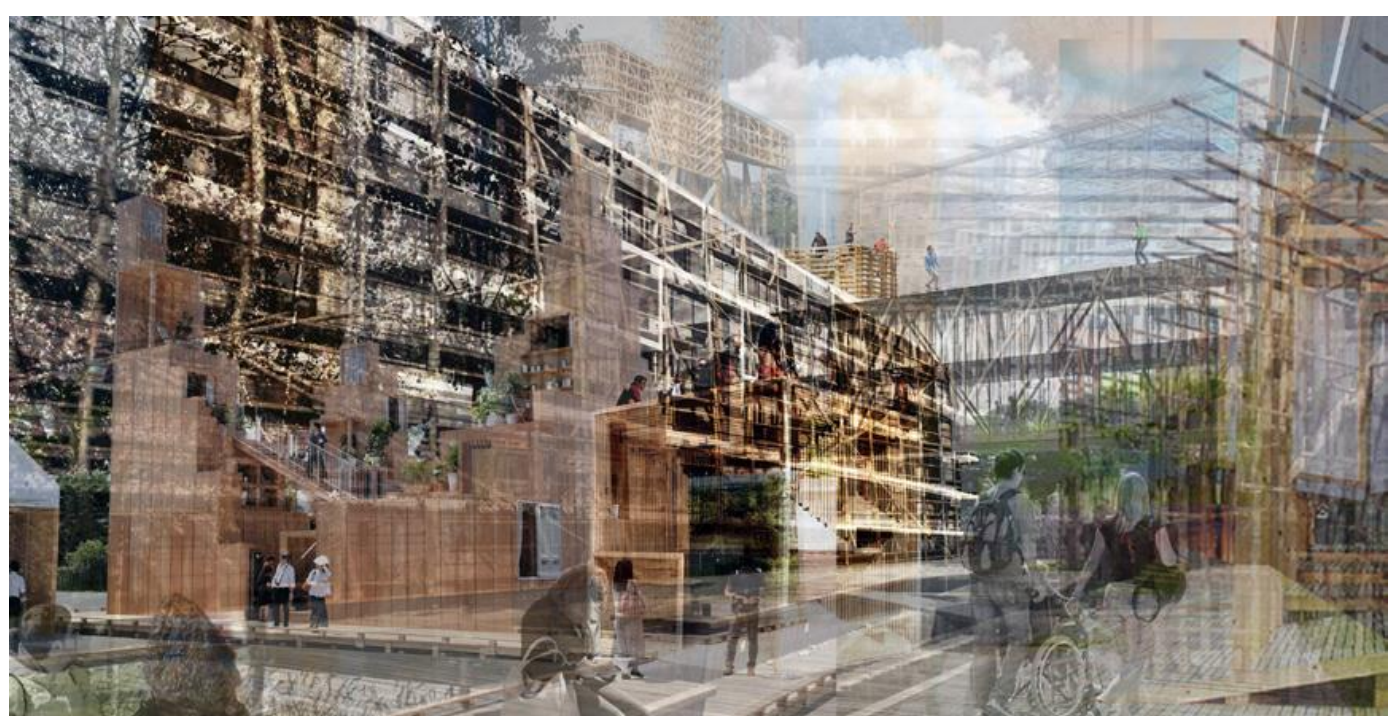

Figure 8 Transformation Kromhoutkazerne: adaptive campus for 'new arrivals'. Self-built topup community from locally produced bamboo (light, biobased and adaptable).
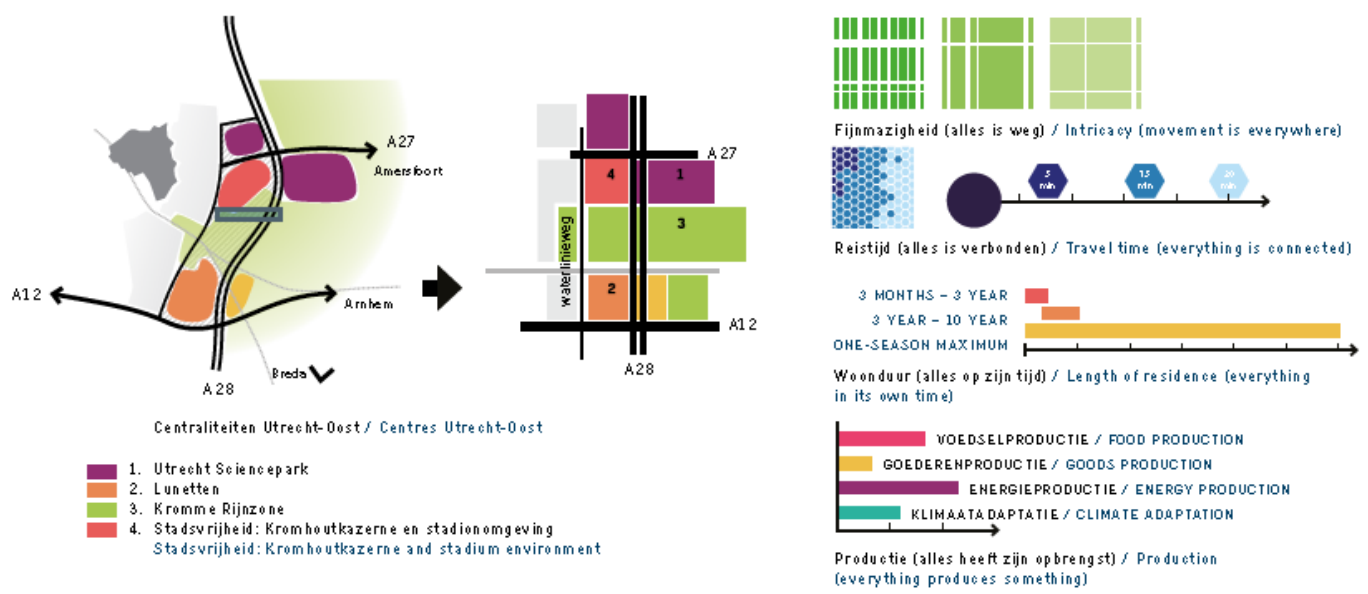

Figure 9

\subsection{Area Mixing Console}

The team translated the contours of the conceptual framework into ordering principles and balanced these using a 'mixing console'. Important principles are: the intricacy of the urban fabric (everything is connected), travel time (everything is proximate), length of residence (everything takes its own time) and varied production (everything is productive). The mixing console allows an alternative method of organizing areas according to functions or density.

A specific mix determines the DNA of a region. The team developed these principles for different locations on the test site. The Kromme Rijn zone, for example, offers space to green pioneers who live and work in a nature-friendly way. No fixed energy network is provided for them, but rather an autarkic system that matches their nomadic lifestyle. In Utrecht Science Park, a higher density of housing and business activity is appropriate.

Living here means using a service, which will suit the lifestyle of temporary residents such as expats and students. 


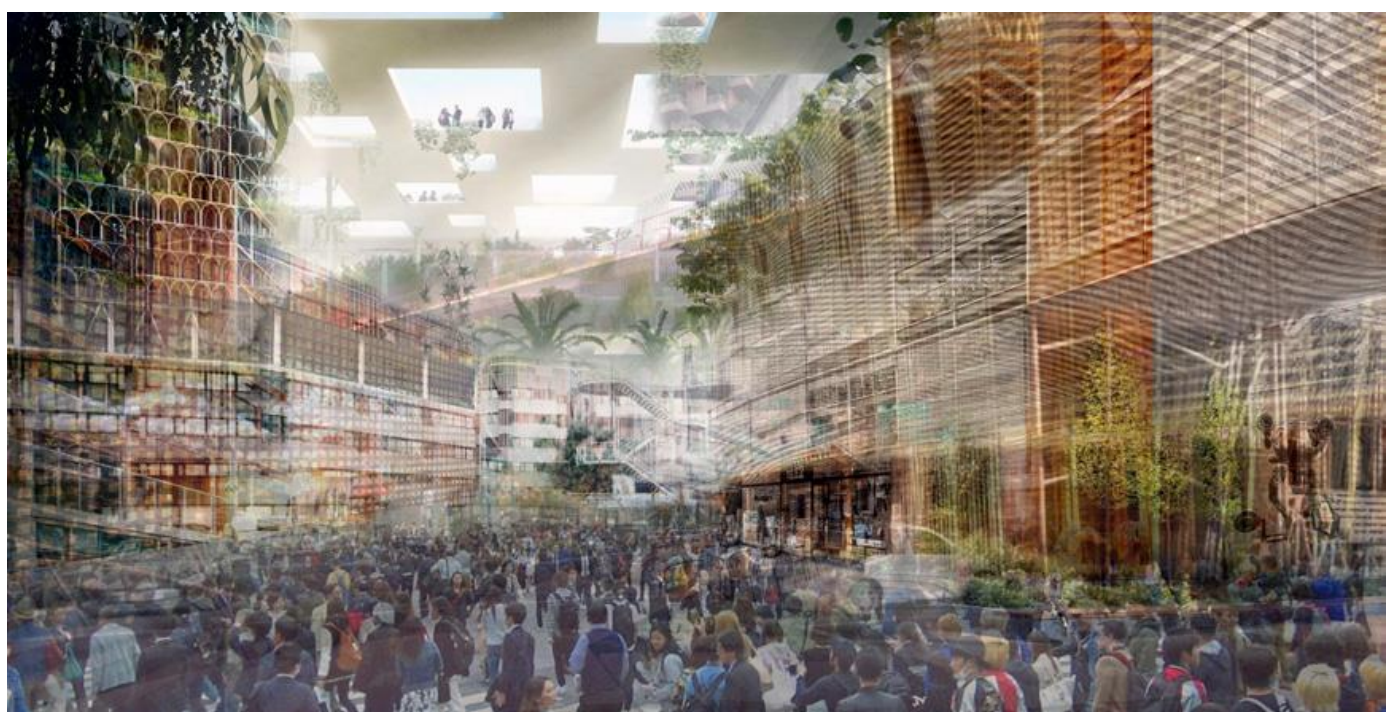

Figure 10 Transformation stadium environment: the high-density heart of Stadsvrijheid with ground floors at various levels. As the crow flies, the area is $\mathbf{1 0 0}$ per cent wadeable and therefore 100 per cent passable.

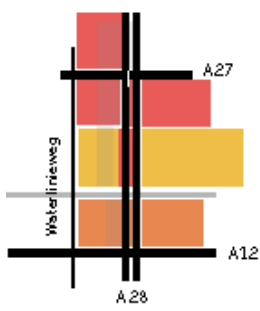

verblijfsduur

3 MONTHS - 3 YERR

W MER. I SERSON

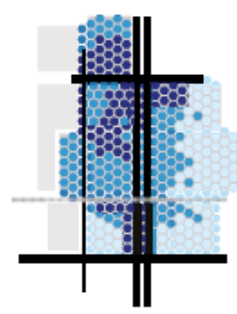

Reistijd te voet
Travel time on foot

5 - 10 MINUTES $10 \cdot 20$ MINUTES $\times 20$ MINUTES

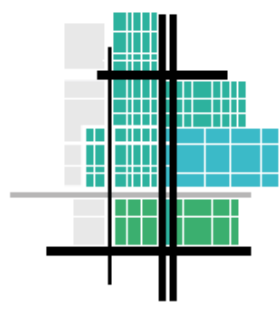

Fijnmazigheid

STMNDQRD INTRICRTE (PASSQBLE RS THE CROW FLIES)
ROBUST (SLOW LaNDSCa PE)

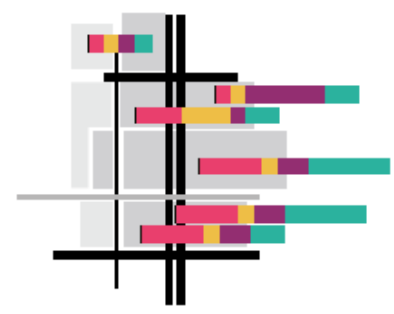

Rela tieve op brengst

FOOD

Goods

ENergy

Figure 11 Mixing console for the area (theme maps). 


\begin{tabular}{|c|c|}
\hline 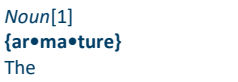 & $\begin{array}{l}\text { meaning housing of infrastructure, such as utility bundles, data, energy, waste, goods [2] layered support } \\
\text { structure for what has not yet been built [3] carrier of urbanization [4] origin arma: equipment [5] synonym setting, } \\
\text { support structure [6] example Armature 27; interurban armature located on former A27 motorway. }\end{array}$ \\
\hline 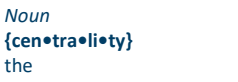 & $\begin{array}{l}\text { [1] meaning source of activity and exchange in urban landscape [2] multifunctional and dense [3] sometimes } \\
\text { coincides with mobipoint (see list) [4] synonym community. }\end{array}$ \\
\hline $\begin{array}{l}\text { Noun } \\
\text { \{foodøboard\} } \\
\text { the }\end{array}$ & $\begin{array}{l}\text { [1] meaning body that promotes the impor tance of circularity [2] local administrative body [3] origin food } \\
\text { forest; production based on the ecological food cycle in an area. }\end{array}$ \\
\hline $\begin{array}{l}\text { Noun } \\
\text { \{he•ri॰tage deal\} } \\
\text { the }\end{array}$ & $\begin{array}{l}\text { [1] meaning investment vehicle developed in connection with the nomination of the New Dutch Waterline for the } \\
\text { World Heritage List for creative petit projects by local heritage corporations. }\end{array}$ \\
\hline $\begin{array}{l}\text { Noun } \\
\text { \{me•an•der\} } \\
\text { the }\end{array}$ & [1] meaning dynamic climate-adaptive landscape [2] origin winding course of a river. \\
\hline $\begin{array}{l}\text { Noun } \\
\text { \{mobiepoint\} } \\
\text { the }\end{array}$ & $\begin{array}{l}\text { [1] meaning point that links routes with mobility-related service providers [2] where supply and demand is } \\
\text { largely determined by market forces [3] social safety and experience are important synonym site. }\end{array}$ \\
\hline $\begin{array}{l}\text { Noun } \\
\text { \{nolli } 2.0\} \\
\text { the }\end{array}$ & $\begin{array}{l}\text { [1] meaning design principle for the walkable city [2] movement as the crow flies through an intricate } \\
\text { network of third places [3] origin map that distinguishes between public and private space. }\end{array}$ \\
\hline $\begin{array}{l}\text { Noun } \\
\text { \{turn }\} \\
\text { the }\end{array}$ & $\begin{array}{l}\text { [1] meaning shif } t \text { in economic and spatial focus from west to east in the twenty-first centur y [2] origin shif } t \text { in power } \\
\text { relations. }\end{array}$ \\
\hline $\begin{array}{l}\text { Verb } \\
\text { \{to un•bun・dle\} }\end{array}$ & $\begin{array}{l}\text { [1] meaning deconstruction of the transport system: infrastructure of transpor t, mobility objects, people, } \\
\text { services based on data, curators, users [2] this leads to the walkable city (see nolli } 2.0 \text { ). }\end{array}$ \\
\hline 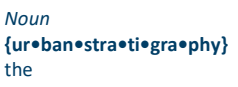 & $\begin{array}{l}\text { [1] meaning urban densification by developing via the Z-axis [2] dense construction near armatures [3] physical } \\
\text { barriers are removed without compromising on the amount of greenery. }\end{array}$ \\
\hline $\begin{array}{l}\text { Noun } \\
\text { \{Utrecht hash•tag\} } \\
\text { the }\end{array}$ & $\begin{array}{l}\text { [1] meaning system of main armatures around the city of Utrecht [2] the armatures form the development axes of } \\
\text { the city [3] the \#hashtag is rooted in the past, and shapes the future [4] carries the development and is the grid } \\
\text { along which people reflect [5] synonym fence; grid [6] origin graphic symbol used on Twit ter to mark keywords in a } \\
\text { message; word or sentence prefixed with the \# symbol. }\end{array}$ \\
\hline 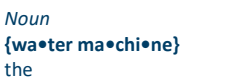 & $\begin{array}{l}\text { [1] meaning landscape system that purifies water and meets the power requirements for the urban system. } \\
\text { Improves quality of life. }\end{array}$ \\
\hline
\end{tabular}

Figure 12 Vocabulary design tools

\subsection{Design Tools}

The team devised new design tools to create the city of the future. 'The armature', for example, is a tool that can be used to redefine the current road infrastructure. Development along the $Z$ axis, for example, is based on the principles of urban stratigraphy and builds on the strata of the existing city. This allows densification and the lifting of the physical barriers of Waterlinieweg and the A27 motorway; the landscape can be layered and brought into the city.

The test site shows the possibilities of the new ordering principles. Embracing change and a variety of governance practices can never produce a clear-cut final picture. That is why the team presents an imagined atmosphere that includes the dynamics of gradual development - with tempting vistas that provide insight into the functioning of the city of the future, but that also raise questions. 

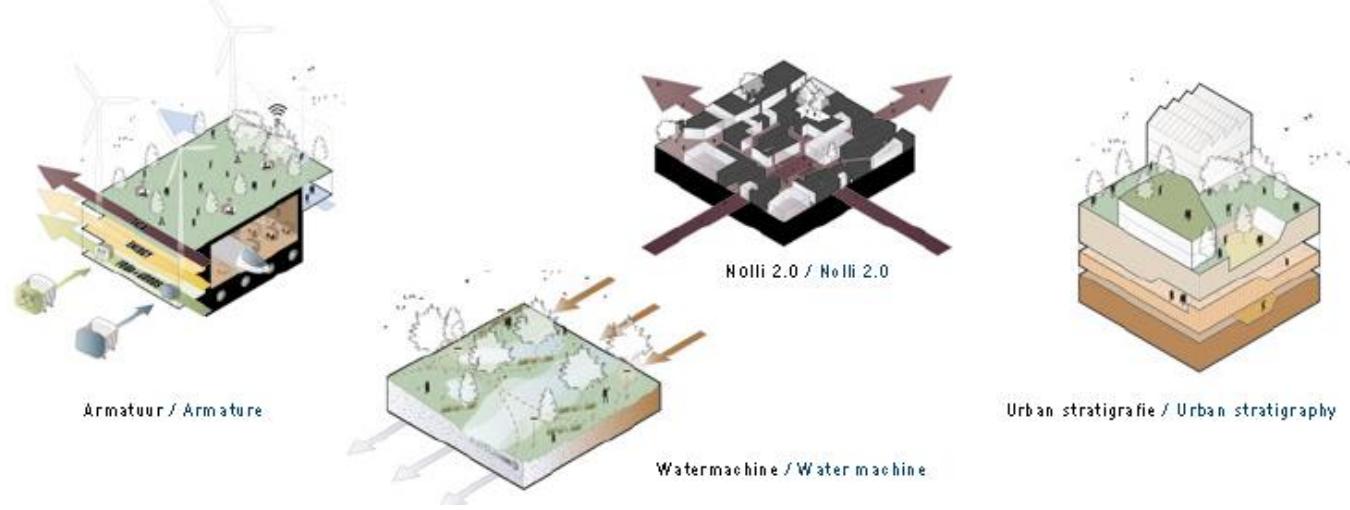

Urb an stratigrafie / U rban stratigraphy

Figure 13

\subsection{A continuous city for pedestrians}

In 2040, city dwellers travel by foot and motorized transport between cities will be connected collectively or individually. Current barriers such as Waterlinieweg and the A27 motorway are hubs that connect Utrecht's future centres. The resulting city is a continuous city for pedestrians that not only allows more density, but in which there is more room for greenery as well. Functions such as roads and housing are layered, stackable, connectable entities linked to new energy and transport networks. They create a productive and endlessly connected urban landscape.

In this layered city everything, including waste, produces something. Everything is designed to last a certain period of time, for example based on length of residence. In this city, the cost of space is the driving force behind change. This comes with new investment models in which the relationship between interest and involvement play a part. The team distinguishes different models for each housing type. The interests and returns of the one housing type can accrue to a residents' collective, for example; other target groups can decide to use housing services, in which case the return and interest are in the hands of owners and investors.

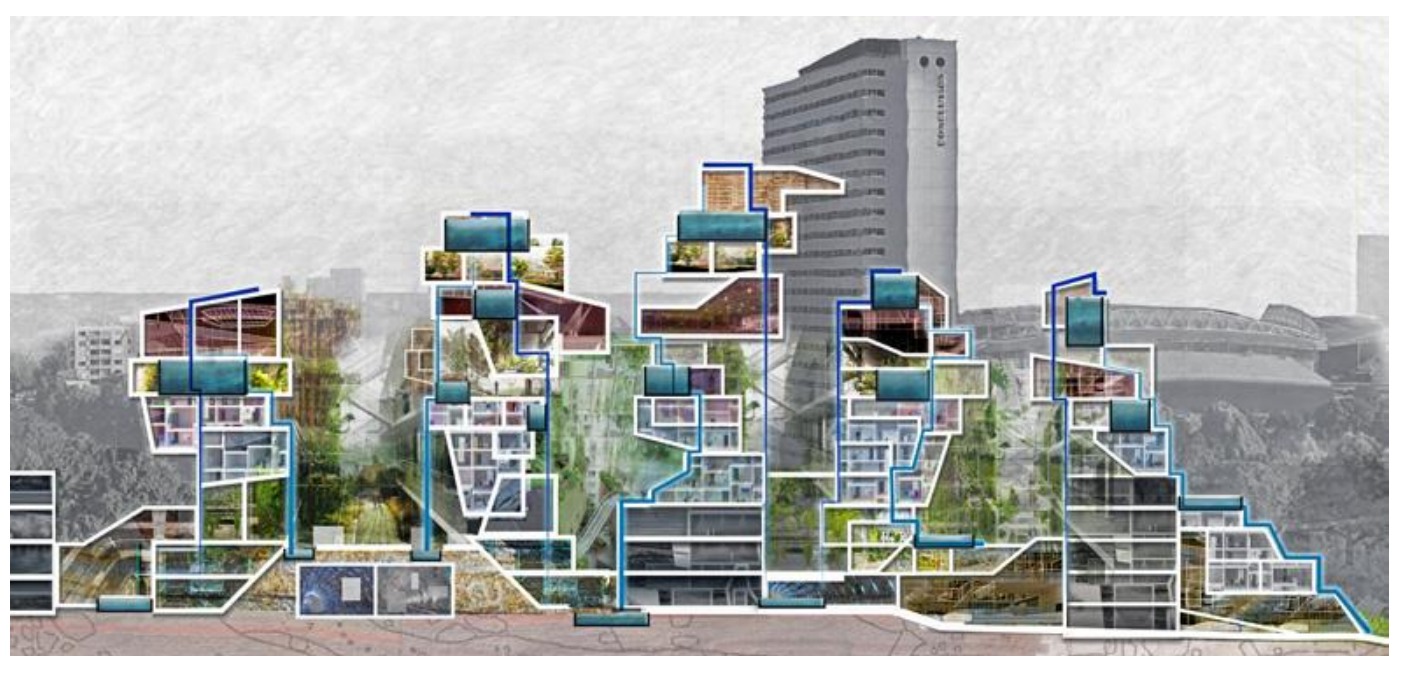

Figure 14 Section Waterlinieweg (implementation of the Armature, Nolli 2.0, Urban stratigraphy). 


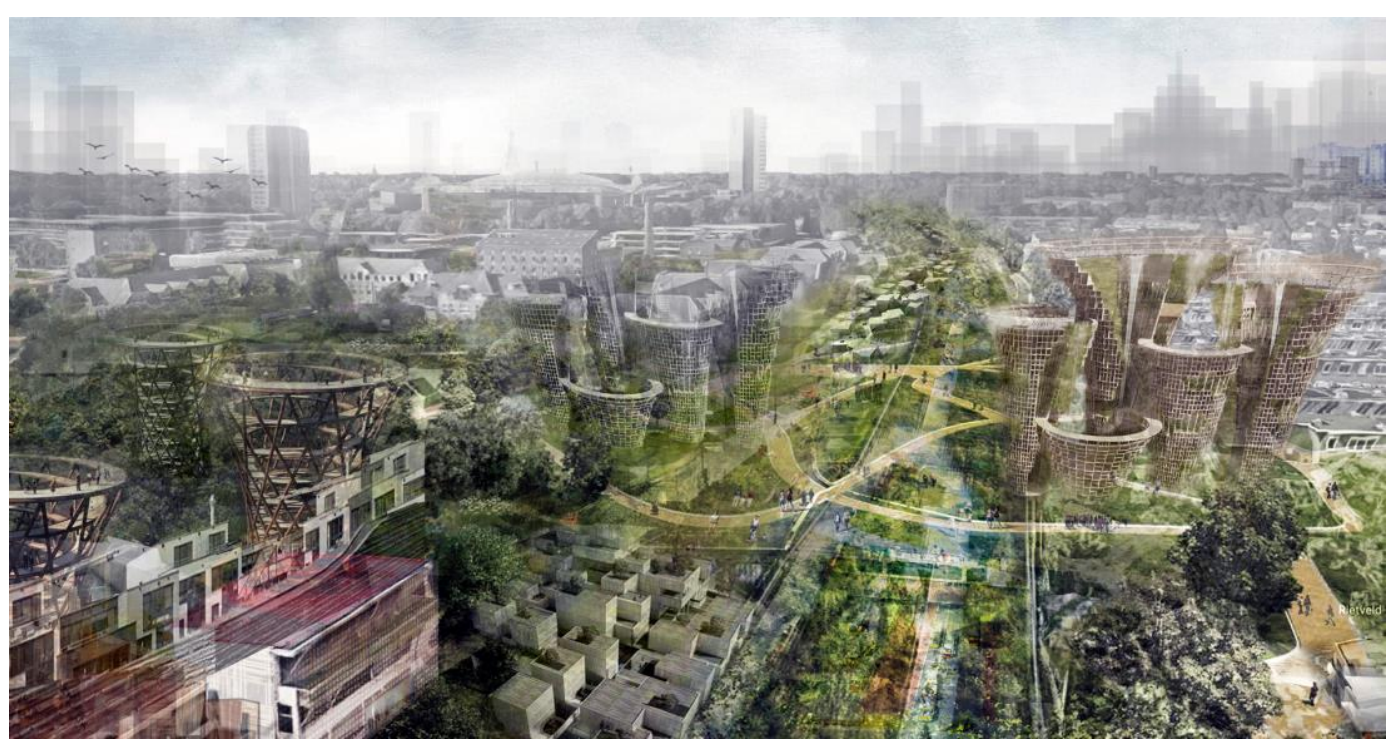

Figure 15 View of Waterlinieweg: foreground left Kromhoutkazerne, foreground right Rietveld Schröder House.

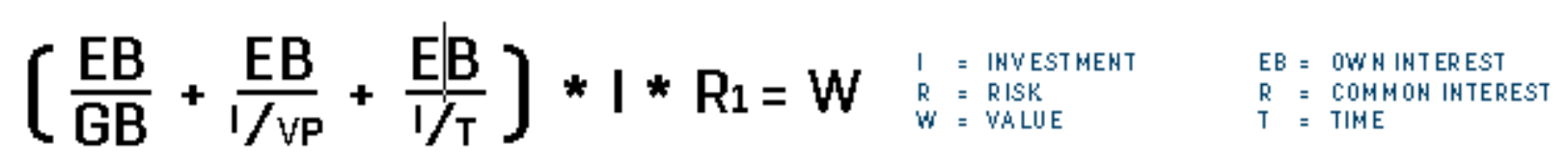

Figure 16 Formula for calculating the value of the city of the future. 